\section{EVALUATION OF THE ELECTRONIC TRADING AS A TOOL FOR PUBLIC HOSPITAL PHARMACEUTICAL SERVICES MANAGEMENT}

Erica Cristina Dourado Silva

Fábio Jorge Ramalho de Amorim Edélzio Alves Costa Júnior Izadora Menezes da Cunha Barros

\title{
ABSTRACT
}

Background: The trading system is one of the main modalities of the bidding process for the acquisition of medicines, mainly through rationalization, agility, transparency of the process and economy.

Objective: To evaluate the influence of the electronic trading processes in the management of public hospital pharmaceutical services.

Methods: This is an observational, transversal and retrospective study, in which the bidding processes for 2015 of a teaching hospital in the state of Sergipe were analyzed. The internal processes and technical opinions, as well as the minutes of the electronic trading sessions available at www.comprasgovernamental.gov.br, were used as sources of information and data collection.

Results: Eight bidding processes were analyzed, with a total of 199 items tendered, of which $25.6 \%$ were unsuccessful and $7 \%$ remained deserted. There was an average of 158.87 days to complete the entire bidding process. The main reasons for the failure of the items were the non-compliance with the documentation required in the bidding process $(42.4 \%)$ and the value of the proposals being above the estimated (17\%). As for the XYZ classification of the failed and deserted items, $18.5 \%$ were classified as of the highest criticality (Z).

Conclusions: The time for completion of the bidding processes was extensive, mainly referring to the internal phase, which ratifies the need to establish deadlines for completion of the steps with the intuition of speeding up the purchase process. Deserted and failed bids may directly influence the patient's clinical outcome due to the shortage of medicines and medical-hospital supplies, and consequently the discontinuity of care provided to the patient.

Keywords: Bidding. Pharmaceutical Services. Hospital Pharmacy Service.

\section{INTRODUCTION}

The medicine is a strategic input to support health actions, its lack may mean constant interruptions in treatment, which affects the quality of life of users and the credibility of the pharmaceutical services and the health system as a whole

The purchase of medicines is one of the main functions performed by the Hospital Pharmacy, which consists of a set of procedures by which the purchase process of medicines is performed, based on an established schedule, with the purpose of supplying the needs of medicines in quantity, quality and lower cost-effectiveness, in addition to maintaining the regularity of the supply system ${ }^{2}$.

In the public service, the purchasing of any material, including medications, follow the rules of contracting of goods and services of the Public Administration, known as the bidding process, exception given to the exemption from bidding and unenforceability. The rules of this formal procedure are described mainly in Laws No. 8,666 / 1993 and 10,520 / 2002, and in Decree No. 5,450 / $2005^{3-5 .}$

The bidding process is the preliminary administrative procedure through which the Public Administration, based on previous criteria, selects, among several proposals referring to purchases, works or services, the one that best serves the public interest, with the purpose of guaranteeing compliance with the constitutional principles of isonomy, impersonality, legality, morality, publicity, administrative probity and attachment to the convening instrument, the objective judgment and those related to it ${ }^{3}$.

The trading system is one of the main modalities of the bidding process for the acquisition of medicines, mainly through rationalization, agility, transparency of the process and saving ${ }^{2}$. The electronic trading system, regulated by Decree No. 5,450, of May 31, 2005, unlike the face-to-face system, is done at a distance, in an electronic form, and it gives a greater openness to the companies to take part of the contest, making it more competitive. This modality has as main function to guarantee speed to the process and reduction of costs ${ }^{6}$.

As for its execution, the trading system is basically formed by two phases: the internal one, constituted by the set of acts and activities that will condition all the development of the bidding process, emphasizing that this phase is initiated with the reference term, and concluded with the publication of the notice; and the external one, which requires the participation of the Administration and third parties, which starts from the announcement of the call notice, being consummated with the process of choosing the best proposal and the future contract ${ }^{7,8}$.
1 Hospital Universitário/ Universidade Federal de Sergipe

Received: $12 / 12 / 2017$

Revised: $31 / 03 / 2018$

Accepted: $31 / 03 / 2018$

How to cite this article: Silva ECD, Amorim FJR, Junior EAC e Barros IMC. Evaluation of the Electronic Trading as a Tool for Public Hospital Pharmaceutical Services Management. Rev. Bras. Farm. Hosp. Serv. Saúde, 9(1): 1-6, 2018.

DOI: 10.30968/rbfhss.2018.091.007

Corresponding author:

Fábio Jorge Ramalho de Amorim Hospital Universitário/ Universidade Federal de Sergipe R. Cláudio Batista, S/N, Palestina, Aracaju. CEP: 49060108. SE- Brasil. ramalhose@hotmail.com 
The notice is the document prepared by the bidding body that includes the detailed description of the object to be tendered, all the rules for the selection and hiring of the interested supplier ${ }^{8}$. When the product to be tendered is a medicine, certain specific documents should be required for technical qualification, based on the law of biddings and complementary legislation, such as:proof of technical capacity (PTC), sanitary license (SL), operating permit (OP) and special authorization (SA), certificate of good manufacturing practices (CBPF), registration with the competent professional entity and registration of the medicine at Anvisa ${ }^{3,9-11}$.

In the hospital environment, the pharmacy service is responsible for several activities with a strong impact on care, such as the purchase of medicines and materials. The inadequate performance of their activities exposes hospitalized patients to not solving their health problem, or even to the possibility of worsening of their clinical condition, either by the unavailability of the necessary medication or by the appearance of adverse events ${ }^{12}$.

Given this context, the monitoring and evaluation of the processes related to the acquisition / purchasing in the hospital Pharmacy Care, such as the Electronic Trading system, are essential to improve the management, preventing the shortage and the discontinuity of the care provided to the patient. Therefore, the objective of this study was to analyze the influence of electronic trading processes in the management of public hospital pharmaceutical services

\section{METHODOLOGY}

This is an observational, cross-sectional and retrospective study, in which the process of purchasing of drugs at the teaching Hospital of Sergipe (HU-UFS) was evaluated.

The Teaching Hospital of Sergipe has been linked to the Federal University of Sergipe (UFS) since 1984, on the management of the Brazilian Company of Hospital Services - Ebserh since 2014. It is fully integrated to the Unified Health System (SUS - "SistemaÚnico de Saúde", in Portuguese language), being a reference in the provision of medical and hospital care of medium and high complexity. Currently, the hospital structure has 123 beds, housing in its dependencies the Medical Clinic, Surgical Clinic, Pediatrics, Adult Intensive Care Unit and Surgical Center, as well as an outpatient complex with 68 offices.

The hospital pharmacy sector participates in the elaboration of the term of reference - document that includes among other information the items and the quantities to be acquired, and the technical analysis of the proposals - in which the technical opinion is issued. The other stages of the process, such as the definition of the reference price, the preparation of the notice and the execution of the trading session are the responsibility of other sectors, such as the purchasing unit and the bidding unit.

The acquisition of medicines at HU/UFS is carried out through the electronic trading system, adopting the Price Registration System, which is inserted in the Bidding Law to speed up the hiring, gaining prominence as an innovative system for purchases by the public administration. Through it, the institution establishes with the supplier a price to be paid for the product offered for a period of one year, for an estimated quantity and the purchases are made according to the need of the institution, thus avoiding waste ${ }^{13}$.

The HU-UFS drug standardization list is composed of about 390 items. The programming of the purchasing of medicines is carried out for 12 months, and the bidding process is carried out preferably in the first half. When the bidding items, for some reason, cannot be acquired in the initial bidding process, a new bid is held. This action is repeated until all items are purchased. In some cases, after repeated attempts, another bidding modality is defined, as well as adherence in current minutes of other federal agencies.

In this study, the bidding processes carried out using the electronic trading modality for the year 2015 were analyzed. In them the technical opinions were verified to identify and evaluate the reason for the failure of the items, mainly regarding the non-compliance with the documentation for the technical qualification required in the notice;the minutes of the electronic trading sessions are available at the electronic address www. comprasgovernamentais.gov.br to identify the quantity of items bid, failures and deserted ones, in addition to evaluating the reasons for failures that go beyond the required documentation; the time to completion of the process was also analyzed.

Faced with important tools to aid in the management of materials such as the $\mathrm{ABC}$ curves (classification according to the monetary value) and $\mathrm{XYZ}$ (classification according to the degree of importance to the productive process), the failing and deserted items were classified only regarding the criticality of their impact on the care, using exclusively the XYZ curve of standardized medicines in the hospital ${ }^{23}$. The most critical items were classified as Z.

The study obtained the consent of the Management of Teaching and Research of the teaching Hospital of Sergipe for the execution, as well as disclosure of the data. Because it was a secondary data research and it did not involve human beings, it was not necessary the approval of an ethics committee.

\section{RESULTS}

The data obtained refer to the nine bidding processes carried out during 2015. Being eight processes for acquisition by item, and one for acquisition by batch, which is characterized by a grouping of several items.

The purchase process per batch included 65 medicines divided into seven batches. The first six failed due to failure to send the documentation required in the bidding notice by the successful bidder, and batch seven failed due to the price that was well above the estimate. The remaining companies were summoned and, subsequently, the first one was resummoned, which gave up maintaining the proposal. For this reason, it is justified not to include this process in the quantitative analyzes of the study.

The time duration of the internal and external phases of the studied processes can be observed respectively in Tables 1 and 2 . In the internal phase, of the eight processes analyzed, two had the procedures performed within 90 (ninety) days, corresponding to $25 \%$. Regarding the external phase, of the eight processes, two concluded the process up to 30 days, corresponding to $25 \%$, and a process had its procedure executed within 120 days, corresponding to $12.5 \%$. On average, 105 days were spent to complete the internal phase and 51 days to complete the external phase. The average for the execution of all bidding processes was 158.87 days.

Table 1: Duration of the processes for acquisition of medicines during the internal phase.

\begin{tabular}{ccc}
\hline Days & Processes & $\%$ \\
\hline $001-030$ & 0 & - \\
$031-060$ & 0 & - \\
$061-090$ & 2 & 25 \\
$091-120$ & 4 & 50 \\
$121-150$ & 2 & 25 \\
TOTAL & 8 & 100 \\
\hline
\end{tabular}

Table 2: Duration of the processes for acquisition of medicines during the external phase.

\begin{tabular}{ccc}
\hline Days & Processes & $\%$ \\
\hline $001-030$ & 2 & 25 \\
$031-060$ & 2 & 25 \\
$061-090$ & 3 & 37.5 \\
$091-120$ & 1 & 12.5 \\
$121-150$ & 0 & - \\
TOTAL & 8 & 100 \\
\hline
\end{tabular}

The quantity of items tendered, failed, deserted and acquired in the processes of purchasing of medicines can be observed in figure 1. Of the eight analyzed processes, 199 items were requested, with $26 \%$ of failures, $7 \%$ of deserted and $67 \%$ of achievement. 


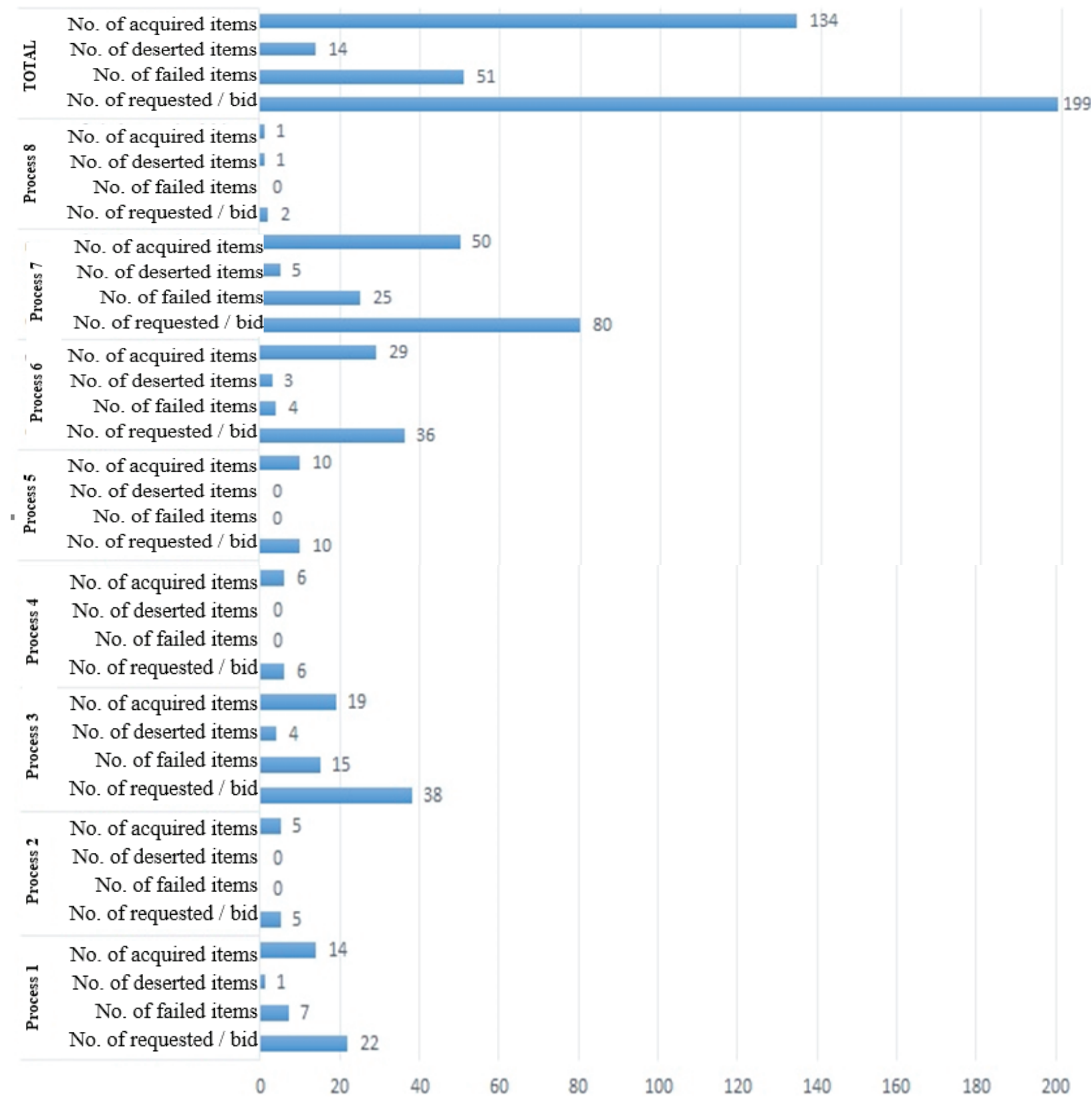

Figure 1: Quantity of items requested, failed, deserted and acquired in the processes of purchasing of medicines by the electronic trading system.

Regarding the reasons for cancellations, it was observed that, of the 51 failed items, 25 had problems with the qualification of the documentation, ten had prices above the estimated value, nine were motivated by the non-sending of the documentation required in the notice (table 3 ). Of the 25 items that presented inconsistencies with the qualification of the documentation, thirteen referred to the Certificate of Good Manufacturing Practices and Control (table 4).
Table 3: Reason for failure of the items

\begin{tabular}{lcc}
\hline Reason for Failure & Frequency & $\%$ \\
\hline Product description & 1 & 1.7 \\
Withdrawal & 5 & 8.5 \\
Required Documents not met & 25 & 42.4 \\
Did not submit original proposal and/or & 7 & 11.9 \\
documentation on time. & 9 & 15.2 \\
Did not submit documentation & 1 & 1.7 \\
Not registered as medicines & 1 & 1.7 \\
Different product than the one requested & 10 & 17 \\
Price above the one estimated & 59 & 100 \\
Total & & \\
\hline
\end{tabular}


Table 4: Reason for failure of the medication items, regarding the noncompliance with the documentation required in the notice.

\begin{tabular}{lcc}
\hline Required Documents not met & Frequency & $\%$ \\
\hline Proof of technical capacity & 0 & 0 \\
State or Municipal Sanitary License; & 2 & 8 \\
Operating Permit & 0 & 0 \\
Special Authorization & 2 & 8 \\
Certificate of Good Manufacturing Practices and & 13 & 52 \\
Control & 8 & 32 \\
Registration at ANVISA & 25 & 100 \\
TOTAL & & \\
\hline
\end{tabular}

Failed and deserted medicines were classified as critical according to the XYZ curve of standardized hospital medications, as can be seen in figure 2 .

Figure 2: XYZ classification of failed and deserted medicines in the processes of purchasing of the drugs studied.

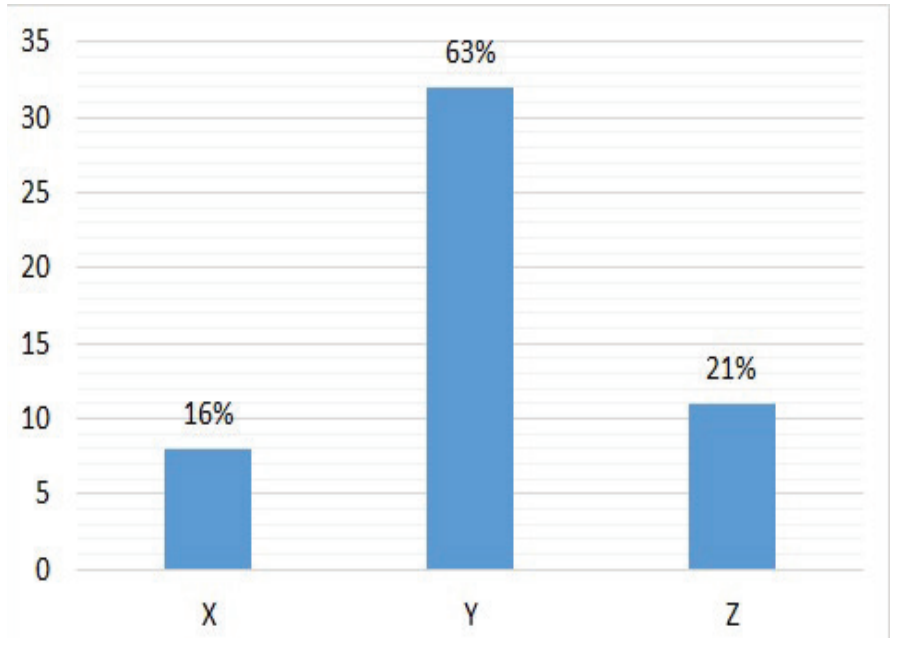

35

30

25

20

15

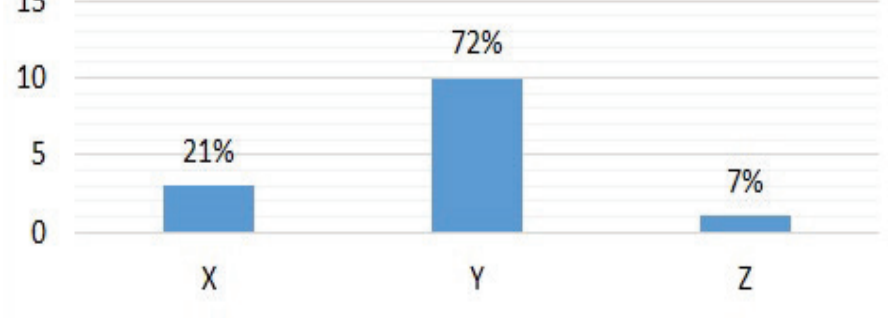

a) XYZ classification of failed medicines b) XYZ classification of deserted medicines

\section{DISCUSSION}

In this study, the duration of the processes for acquisition of medicines during the internal phase was longer when compared to the external phase. In the study carried out by Monteiro et al. (2009), in which the bidding processes by electronic trading at the Teaching Hospital of Maranhão were analyzed, the duration time of the internal phase was lower than that of the external phase, where all the internal bidding processes were completed within 120 days, whereas in the present study only $75 \%$ of the processes had been completed during this period. Therefore, it is observed that the hospital studied is investing a lot of time in the internal phase, delaying the completion of the process, what may lead to shortages.

When analyzing each stage of the internal phase of the bidding processes, it was observed that in two processes were spent on average 80 days to prepare the notice, while in another process were spent only five days. As for the scheduling of the trading session, a stage that was carried out after the bidding process, three processes spent an average of 30 days. Highlighting the extension of some stages, which suggests the need to define deadlines for the completion of each stage, as well as a monitoring, in order to observe the work processes and propose improvements to make it faster and more effective.

When analyzing the deadline for the completion of all bidding process, internal and external phases, an average of 158.87 days were spent to conclude it, which was lower when compared to the study done by Fontenele and Oliveira (2015) on the evaluation of the stage of medication acquisition of the Public Hospital Care of Teresina, Piauí, which was 184 days. This divergence of values is probably due to the internal routines adopted in each organ, as well as the average number of items tendered by the process, which in the cited study is 90.5 items, in the present study it was 37.2 items (the processes of acquisition of medicinal gases and parenteral nutrition for the analysis of this data were not included).

The biddings may be classified as failed or deserted, the former are characterized when there are participants in the bidding process, but all are disabled or all tenders are disqualified, whereas the deserted tenders are characterized when bidders do not appear in the bidding procedure performed ${ }^{7}$. In the analyzed period, of the 199 items tendered, $25.6 \%$ failed, a result very close to the study by Bevilacqua et al (2011), in which $27.6 \%$ of the items failed. Both presented higher results than the study by Monteiro et al (2009), in which $39.8 \%$ of the items failed.

There may be several reasons for the items to fail, in the case of the present study, the main reasons were the non-compliance with the documentation required in the public notice, the value of the proposals being above the one estimated, and documents not submitted. Among the studies analyzed, only the study by Monteiro et al (2009) evaluated the reasons for the failure to purchase the items, being highlighted price above the one estimated, non-compliance with the documentation required in the notice, and documents not submitted. It is noticed that the reasons of the failures were the same in both studies, only reversing the order of importance. The probable justification of the "above-estimated price" not being the main reason for the failure of this study may be the methodology adopted for the price survey, in which the query of the price bank is used, where only the most recent tenders are taken into account.

The Certificate of Good Manufacturing Practices and the registration of the medicine at Anvisa were the main causes of the reason for the failure of the items regarding non-compliance with the documentation required in the notice. Together with the Sanitary License and the Operation Permit are the documents that guarantee the quality of the medicines to be purchased.

According to Law No. 9,782 of January 26, 1999 and the RDC of April 16, 2014 of ANVISA, the AFE should be renewed annually. With Law No. 13,043 of November 2014, this obligation of annual renewal for all companies was extinguished, only being necessary the AFE at the time of opening of the companies. Regarding the CBPF requirement, the Court of Audit of the Union (TCU - "Tribunal de Contas de União", in Portuguese language) considers that it is not mandatory, because it offends the principle of legality, as it is not described in Law 8,666 / 93, besides not 
being indispensable to the guarantee of the fulfillment of the obligations to be assumed before the contracting body, and that the registration of the product at Anvisa would already be sufficient, since the manufacturer when filing the registration should already own the CBPF $(17,18)$. On the other hand, Law No. 9,782 of January 26, 1999 and the RDC No. 17 of April 2010, which are part of the scope of the Brazilian sanitary legislation, emphasize the importance of the requirement and renewal of aforementioned document, as well as the establishment of the minimum requirements to be followed in the manufacture of medicines.

Since 2016, the bidding processes of the institution studied were prepared in order to meet the TCU requirement and Law No. 13.043/14, that is, the $\mathrm{CBPF}$ is no longer required as a mandatory item in the technical qualification, and regarding the AFE, the requirement is maintained, and no renewal is required. Thus, it is likely that there will be a significant reduction of failures in relation to non-compliance of the documents required for qualification, since together CBPF and AFE accounted for more than half of the cases.

The deserted items were responsible for $7 \%$ of the failures of the bidding processes, with a greater emphasis on low value items. Fact ratified by the study of Yang et al. (2016), which states that one of the major reasons for bidders' lack of interest is a combination of weak demand and low prices. As an initiative for the success of the acquisition process of these items, the institution studied adopted a purchasing mechanism that would allow greater interest on the part of the bidders, and a reference term of purchase per batch was drawn up, in which there was no failure. Despite the participation of some distribution companies, it was verified that with the composition of the batches based on the therapeutic classes, the direct participation of the pharmaceutical industries was made difficult, thereby reducing the widespread competition and increasing the likelihood of further failures.

In view of the fact, it is perceived that a process of purchase by batch, when duly justified its realization, it should be elaborated not by therapeutic class in an isolated way, but by associating this criterion with items produced by some laboratories, so as not to target specific distributors or manufacturers, thus increasing competition and providing the purchase for lower prices.

The deserted and failed items were classified according to the criticality using the XYZ classification of standardized HU/UFS medicines. According to this classification, the lack of high-critical class $Z$ materials paralyzes essential operations and endangers patients, the work process and the institution ${ }^{20}$. Of the 65 items that underwent criticality analysis, $18.5 \%$ were classified as having the highest criticality. Of these, none were discontinued or missing in the Brazilian market.

Norepinephrine and insulin are some examples of drugs that are considered essential drugs of high criticality $(\mathrm{z})$ and therefore cannot be replaced by other equivalents in a timely manner to avoid disruptions ${ }^{21}$. With the objective of avoiding risks to care, and consequently increasing healthcare costs, the institution under study successfully performed simplified purchasing procedures such as adherence to current price registers of other institutions of the same governmental sphere.

Medicine shortages of both low criticality items and high criticality items influence all stakeholders in health care, especially patients and hospitals, leading to public health problems. The absence of medications for patients can lead to incomplete care and delays or cancellation of treatments and/or surgeries. Patients may also present evaluation errors, adverse outcomes, and increased health costs ${ }^{19}$.

The lack of medication compromises the safety of the care process and increases the likelihood of medication errors and adverse drug reactions, especially when a therapeutic plan has to be replaced by the absence of a treatment and not by a clinical need of the patient ${ }^{22}$. In addition, it gives rise to a problem related to medication of need, since the patient with a certain health problem may not receive the necessary treatment for not having the indicated medicine available in the institution.

The shortage of medicines, either due to poor programming or failures in the purchasing process, has negative consequences for the management of the Hospital Pharmacy Care, such as depreciation of the institution's image, service shutdown, the possibility of more expensive and urgent purchases, as well as commitment to patient safety ${ }^{23}$.

\section{CONCLUSION:}

The data presented in the study demonstrate that the time to complete the bidding processes was extensive, mainly referring to the internal phase, ratifying the need to establish deadlines for completing the steps with the aim of speeding up the purchase process. The elaboration of the notice with an adequate number of items (between 40 and 50) would be another way to make the bidding process faster.

With the current laws and judgments regarding the AFE and the CBPF, and the adoption of the same by the institution studied in the preparation of the notices, probably less failures will occur in the future bidding processes, justifying the performance of new studies to evaluate the occurrence of scenario change.

To avoid failures in the care process due to the shortage of items of high criticality ( $\mathrm{z}$ ) after failed bidding process, it becomes imperative to adopt a purchasing methodology that requires less time, such as adherence to the current protocol. It must be carried out in parallel with the preparation of the new term of reference.

Studies on this theme need to be encouraged, since a shortage of work in this area has been identified.

In view of the above, the present study reinforces that the process of purchasing medicines in the public sector is a complex and essential step for Pharmaceutical Services, being its evaluation indispensable for the proposition of improvements in the process, besides emphasizing its critical role, since it directly influences other steps, such as the purchase schedule and the clinical outcome of the patient.

\section{Financial Suport}

The research did not receive financing for its realization.

\section{Confict of Interests}

The authors declare no conflicts of interest.

\section{REFERENCES}

1. Brasil. Ministério da Saúde. Secretaria de Ciência, Tecnologia e Insumos Estratégicos. Departamento de Assistência Farmacêutica e Insumos Estratégicos. Aquisição de medicamentos para a Assistência Farmacêutica no SUS. Brasília, 2006. Disponível em: < http://www. ensp.fiocruz.br/portal-ensp/judicializacao/pdfs/284.pdf. Acesso em: dezembro de 2016.

2. Fontenele RP, Oliveira, TJC. Avaliação da etapa de aquisição para avaliação da gestão da Assistência Farmacêutica Hospitalar Pública. Revista Brasileira de Farmácia Hospitalar, 2015, 6(3):18-22.

3. Brasil. Congresso Nacional. Lei n 8.666 , de 21 de junho de 1993. Regulamenta o art. 37, inciso XXI, da Constituição Federal, institui normas para licitações e contratos da Administração Pública e dá outras providências. Diário Oficial da União, Brasília, 22 jun. 1993.

4. Brasil. Lei $n^{\circ} 10.520$, de 17 de julho de 2002. Instiui, no âmbito da União, Estados, Distrito Federal e Municípios, nos termos do art. 37, inciso XXI, da Constituição Federal, modalidade de licitação denominada pregão, para aquisição de bens e serviços comuns, e dá outras providências. Diário Oficial da União, Brasília, 18 jul. 2002.

5. Brasil. Decreto no 5.450, de 31 de maio de 2005. Regulamenta o pregão, na forma eletrônica, para aquisição de bens e serviços comuns, e dá outras providências. Diário Oficial da União, Brasília, jun. 2005.

6. Maciel MJN, Cavalcante PF, Lisboa TS, et. al. A modalidade pregão: vantagens e desvantagens de sua aplicação no município de Santa 
Izabel do Pará. Revista de Administração e Contabilidade, 2014, 1(0).

7. Brasil. Tribunal de Contas da União. Licitações e Contratos Orientações e Jurisprudência do TCU. Brasília, 2010. Disponível em: < http://portal.tcu.gov.br/lumis/portal/file/fileDownload.jsp?inlin $\mathrm{e}=1$ \&fileId=8A8182A24D6E86A4014D72AC81CA540A. Acesso em: dezembro de 2016 .

8. Maia, DEC. Pregão: Uma análise do processo de aquisição de bens e serviços comuns pela Administração Pública. In: Âmbito Jurídico, Rio Grande, XIII, n. 79, 2010.

9. Brasil. Lei no 9.782 de 26 de janeiro de 1999. Define o Sistema Nacional de Vigilância Sanitária, cria a Agência Nacional de Vigilância Sanitária, e dá outras providências. Diário Oficial da União, Brasília, 27 jan. 1999.

10. Brasil. Ministério da Saúde. Agencia Nacional de Vigilância Sanitária. RDC n ${ }^{\circ} 16$, de $1^{\circ}$ de abril de 2014. Dispõe sobre os Critérios para Peticionamento de Autorização de Funcionamento e Autorização Especial (AE) de Empresas. Diário Oficial da União, Brasília, 2 abril de 2014.

11. Brasil. Ministério da Saúde. Agencia Nacional de Vigilância Sanitária. RDC no 17, de 16 de abril de 2010. Dispõe sobe as Boas Práticas de Fabricação de Medicamentos. Diário Oficial da União, Brasília, 2010.

12. Torres RM, Pepe VLE, Osorio-de-Castro CGS. Aspectos da Avaliação de Serviços na Farmácia Hospitalar Brasileira. Revista Brasileira de Farmácia, 2011, 92(2):55-59.

13. Sforsin ACP, Souza FS, Sousa MB, et. al. Gestão de Compras em Farmácia Hospitalar. Farmácia Hospitalar, 2012, 16 (0): 1-32.

14. Monteiro F, Rodrigues JR, Araujo LC. et. al. Pregão eletrônico para aquisição de medicamentos: experiência de um hospital universitário. Revista do Hospital Universitário da Universidade Federal do Maranhão, 2009, 10(2):50-57.

15. Bevilacqua G, Farias MR, Blatt CR. Aquisição de medicamentos genéricos em município de médio porte. Revista de Saúde Pública, 2011, 45 (3): 583-9.

16. Brasil. Lei n 13.043, de 13 de novembro de 2014. Diário Oficial da União, Brasília, nov. 2014.

17. Brasil. Tribunal de Contas da União. Acórdão n³92/2011. Processo: 033.876/2010-0. Relator: Ministro José Jorge. Brasília, 2011.

18. Brasil. Tribunal de Contas da União. Acórdão n 4788/2016. Processo: 001.103/2015-6.Relator: Ministro Bruno Dantas. Brasília, 2016.

19. Yang C, Wu L, Cai W, et. al. Current Situation, Determinants, and Solutions to Drug Shortages in Shaanxi Province, China: A Qualitative Study. PLoS ONE, 2016, 11 (10): 1-16.

20. Mendes KGL, Castilho V. Determinação da importância operacional dos materiais de enfermagem segundo a Classificação XYZ. Rev Inst Ciênc Saúde, 2009, 27(4): 324-9.

21. Lourenço KG, Castilho V. Nível de atendimento dos materiais classificados como críticos no Hospital Universitário da USP. Rev Bras Enferm, 2007, 60 (1): 15-20.

22. Reis AMM, Perini E. Desabastecimento de medicamentos: determinantes, consequências e gerenciamento. Ciência \& Saúde Coletiva,
2008, 13(Sup): 603-610.

23. Barbieri JC,Machline C. Logística hospitalar: teoria e prática. São Paulo: Saraiva; 2006. 